\title{
Biological treatment of crop residues for ruminant feeding: A review
}

\author{
M. S. Mahesh^ and Madhu Mohini \\ Dairy Cattle Nutrition Division, National Dairy Research Institute (Deemed University), Karnal, Haryana-132 001.
}

Accepted 1 July, 2013

\begin{abstract}
Crop residues are often referred to as 'lignocellulosics' as they are rich in cellulose which is bound with a biopolymer lignin. Rumen microbiota (bacteria, protozoa and fungi), even with their hydrolytic enzymes, are not very competent enough to break these bonds efficiently. Biological treatment of such crop residues using white rot fungi (WRF) can break the ligno-cellulose complexes, liberating free cellulose and thus enhancing their feeding value for ruminants. Biologically treated roughages have higher digestibility for most of the nutrients (both cell walls and cell solubles) with an increase in crude protein content as compared to untreated material, besides ensuring more fermentable substrates in the rumen. Further, recent studies have indicated low methane emission from feedstuffs subjected to solid state fermentation (SSF) with ligninolytic fungi as a result of their improved digestion and nutrient assimilation. This review primarily deals with the nature and composition of crop residues, their inherent nutritive constraints as ruminant feed and to overcome the same by means of biological treatments. The progresses to date in in vitro and in vivo studies on biologically treated lignocellulosics have also been reviewed.
\end{abstract}

Key words: Crop residues, ligninolytic fungi, ruminant, digestibility, methane.

\section{INTRODUCTION}

Ruminant animals in many tropical countries subsist mainly on crop residue based diets. The increasing expansion of agro-industrial activity over the last few years has led to the accumulation of a large quantity of lignocellulosic residues all over the world. In India, the major agro-residues in terms of volumes generated (in million metric tons, MMT) were found to be rice straw (112), rice husk (22.4), wheat straw (109.9), sugarcane tops (97.8) and bagasse (101.3) (Saritha et al., 2012). Although a vast energy potential is locked in these lignocellulosic crop residues (Jung, 1989), these are not utilized to their fullest potential for ruminant feeding due to poor digestibility, low nitrogen and mineral contents which rendered them to be classified under non-maintenance type of feeds. Also, the covalent encrustation of plant cell wall with lignin prevents their biodegradation in the rumen. Therefore various physical and chemical treatments have been tried, which are known to improve feed quality either by increasing digestibility or by enhancing palatability. However, these treatments have their own limitations and few are environment unfriendly (Silverstein et al., 2007). Recently, the biological treatments of crop residues to improve the accessibility of cellulosic fractions, thus improving their digestibility and feeding value have been attracting the extensive interests among researchers (Zhang et al., 2007; Yu et al., 2009) although this process has a long history. The major obstruction in biological conversion of lignocelluloses is the physical protection of cellulose by lignin against cellulolytic enzymes. The potential of biological treatments has been explained by the ability of certain microbes (specifically basidiomycetes fungi) to disrupt plant cell wall by 
Table 1. Chemical composition of commonly used cereal straws (\% DM) for livestock feeding.

\begin{tabular}{lcccc}
\hline Particular & Wheat straw & Rice straw & Barley straw & Oat straw \\
\hline Lignin & $8.5-15$ & $6-10$ & 11.0 & 14 \\
$\mathrm{NDF}$ & $75-82$ & $65-80$ & 80 & 70 \\
$\mathrm{ADF}$ & $51-64$ & $49-59$ & 59 & 47 \\
$\mathrm{SiO}_{2}$ & $1-5$ & 13 & 2 & $2-5$ \\
\hline
\end{tabular}

Compiled from Singh and Oosting (1993), Prasad et al. (1993) and Van Soest (2006).

partial breakdown of the lignin-carbohydrate complex (Keller et al., 2003) thus improving their utilization in the rumen by increasing the availability of fermentable energy to ruminal microbes (Akin et al., 1993). This way, basidiomycetes seems to be the most promising microorganisms for biological pre-treatment and among them the selective lignin degrading WRF holds immense importance (Akhtar et al., 1997; Yu et al., 2009) in enhancing the utilization of poor quality roughages for animal feeding. WRF such as Phanerochaete chrysosporium, Pleurotus sp., Lentinus edodes, Coriolus versicolor, Phlebia sp. and Ceriporiopsis subvermispora have largely been studied for their ability to ferment different crop residues (wheat straw, olive mill solid waste, madake bamboo, tanniniferous lespedeza plants, oil palm fronds etc.) to produce improved animal feed (Zafar et al., 1989; Yadav and Tripathi, 1991; Moyson and Verachtert, 1991; Tripathi and Yadav, 1992; Akin et al.,1996; Basu et al., 2002; Shabtay et al., 2009; Okano et al., 2009; Hassim et al., 2012). P. chrysosporium fungi degrades lignin to the extent of 65 to $70 \%$ while others like Ganoderma applanatum and Coriolus versicolor degrade over $45 \%$ of lignin in lignocellulosic materials (Gupta et al., 1993). Thus, microbial conversion seems to be a practical and promising alternative for increasing the nutritional value of agro by-products by transforming them into animal feed and producing a value-added product (Villas-Bôas et al., 2002).

\section{NATURE AND CHEMICAL COMPOSITION OF STRAWS AND OTHER AGRICULTURAL BYPRODUCTS}

Straws are being used as a livestock feed ever since the advent of cereal cultivation as they are inevitably produced as cereal by-products.

Prasad et al. (1993) distinguished two major groups of straws as follows: a) Slender straws: rice, wheat, oats; b) Coarse straws: millet, sorghum.

Although straw is an important feedstuff, and indeed the staple feed in large parts of the developing world for ruminants, it is not preferred by animals. A characteristic of straw is that it mainly consists of highly lignified cell wall material, which often constitutes upto $80 \%$ of the dry matter. This consists of major proportions of cellulose, hemicellulose and lignin which occur in the ratio 4:3:3, respectively (Theander and Aman, 1984), while the rest comprises of nitrogenous compounds and ash. Cereal straws normally contain at least $70 \%$ carbohydrates and are therefore, a potential source of energy for livestock, which can be utilized through microbial fermentation in the rumen. Nutritive value of straw is controlled by the chemical attributes of straw that limit the digestion of cellulose and hemicellulose. These attributes include lignification, silicification, crystallinity of cellulose, etc. which are known to be the inherent nutritive constraints in straw. Even though these residues contain enough cellulose to make them an excellent source of energy for ruminants, these are poor quality feeds in their natural state because of their low protein content (2.5 to 6\%) (Khilberg, 1972) associated with high lignin (7 to 14\%). The major part of the protein is most likely associated with the cell-walls which are known to have low digestibility. Thus, it is unlikely that any straw without supplementation can sustain the nitrogen balance in animals. There appears to be a curvilinear effect of supplementation on intake of straw (Prasad et al., 1993). Generally, straws like wheat straw contains (on dry matter basis) 85 to $94 \%$ organic matter $(\mathrm{OM}), 2.5$ - to $5 \%$ crude protein (CP), 40 to $44 \%$ crude fibre (CF), 45 to $46 \%$ nitrogen free extractives (NFE), 0.16 to $0.22 \%$ calcium and 0.05 to $0.14 \%$ phosphorus. The chemical composition and energy contents of agricultural by-products are presented in Tables 1,2 and 3 , respectively.

\section{CHARACTERISTICS OF POLYSACCHARIDES IN STRAWS}

STRUCTURAL

Plant cell wall contains three types of structural polysaccharides, namely cellulose, hemicelluloses and pectic polysaccharides. In straws, the polysachharide composition is rather simple, with cellulose and xylans as the predominant components (Theander and Aman, 1984) along with smaller amount of polysaccharides containing mannose, galactose and probably pectic components. Cellulose in plants is composed of both crystalline and amorphous structure. The degree of crystallinity is believed to affect the rate of its decomposition by cellulolytic organisms; the greater the degree of crystallinity, the slower is the rate of microbial cellulose degradation (Fan et al., 1981). Although the cellulose of wheat straw can be utilized by ruminant animals, digestibility often is limited by its low protein content and a high degree of 
Table 2. Cell wall composition of some agricultural byproducts $\left(\mathrm{g} \mathrm{kg}^{-1} \mathrm{DM}\right)$.

\begin{tabular}{lcccc}
\hline Roughage & Cell wall & Hemicellulose & Cellulose & Lignin \\
\hline Barley straw & 810 & 270 & 440 & 70 \\
Oat straw & 730 & 160 & 410 & 110 \\
Paddy straw & 790 & 260 & 330 & 70 \\
Wheat straw & 800 & 360 & 390 & 100 \\
Sorghum stover & 740 & 300 & 310 & 110 \\
Chickpea straw & 620 & 200 & 300 & 100 \\
Lucerne straw & 690 & 190 & 380 & 110 \\
Sugarcane bagasse & 820 & 290 & 400 & 130 \\
Sugarcane trash & 800 & 260 & 360 & 100 \\
Paddy hulls & 860 & 140 & 390 & 110 \\
Cottonseed hulls & 910 & 150 & 590 & 130 \\
\hline
\end{tabular}

Adapted from Jackson (1977).

Table 3. Energy content of straws (MJ kg $\left.{ }^{-1} \mathrm{DM}\right)$.

\begin{tabular}{lccccc}
\hline Straw & GE & $\mathbf{D E}$ & $\mathbf{M E}$ & $\mathbf{N E}_{\mathbf{m}}$ & $\mathbf{N E}_{\mathbf{g}}$ \\
\hline Wheat straw & 18.0 & 7.5 & 6.2 & 2.7 & 0.5 \\
Rice straw & 16.7 & 7.5 & 6.2 & 2.7 & 0.4 \\
Barley straw & 16.3 & 7.5 & 6.1 & 2.5 & 0.3 \\
Bermuda straw & 18.4 & 11.3 & 9.1 & 5.5 & 3.1 \\
\hline
\end{tabular}

Adapted and modified from NRC (1982). GE, Gross energy; DE, digestible energy; ME, metabolizable energy; $\mathrm{NEm}$, net energy for maintenance and NEg, net energy for gain, respectively.

lignification. Hemicelluloses are alkali soluble cell wall polysaccharides that are closely associated with cellulose (McDonald et al., 2009). Other organic molecules like cutin and suberin have been reported to be closely associated with carbohydrates in the cell wall of plants (Kolattukudy et al., 1981).

Physical incrustation of plant fibers by means of lignocarboydrate complex renders them inaccessible to chemical degradation and for enzymes that would normally digest them. Strong chemical bonds which exist between lignin and many plant polysaccharides and cell wall proteins render these compounds unavailable during digestion as the digestibility is generally inversely correlated to the amount of lignin in the substrate (Han, 1975). The soluble phase of silica is also associated with lowered digestibility of straw (Van Soest and Jones, 1968). Further, Van Soest (1994) stated that lignin is the single most responsible factors for reducing digestibility of forages and the reported digestibility values for the straws of wheat, barley, rice and oats ranges 40-55, 48-50, 40-55 and 45$50 \%$, respectively (Van Soest, 2006). Therefore, removal of lignin has become a prerequisite for the efficient utilization of carbohydrates from lignocelluloses besides improving their palatability.

\section{LIGNINOLYTIC MICROORGANISMS}

Ligninolytic microorganisms are mainly wood inhabiting fungi. They are able to colonize different plant residues
(Zadražil, 1976, 1979) and increase the digestibility of the substrate (Kirk and Moore, 1972). The ideal microorganism for upgrading lignocellulosics into animal feed should combine high ligninolytic capability with low degradation of cellulose and hemicelluloses. Following three major aerobic ligninolytic fungi are known to play a major role in lignin degradation of straw (FAO, 2011).

\section{Brown-rot fungi}

Brown-rot fungi preferentially attack cellulose and hemicellulose, leaving lignin intact, thus, decaying residue turning brown. Brown rot fungi are mainly humifiers causing only limited changes in lignin. They do not cleave lignin's aromatic ring efficiently, or if they open the rings, they are unable to make significant decomposition resulting in lignin fragments. These results in lower in vitro digestibility compared to untreated substrate (Zadražil et al., 1999). The examples are Agrocybe aegeritaand Flammulina velutipes.

\section{White-rot fungi}

White-rot fungi are capable of degrading lignin without affecting much of cellulose and hemicelluloses (Zadražil and Brunnert, 1982) thus causing decayed residue to turn white. WRF attack unaltered lignin polymers causing cleavage of interlignol bonds and aromatic ring cleavage, 
which ultimately results in an increase in in vitro digestibility (Zadražil et al., 1999). They mainly degrade polysaccharides by hydrolytic enzymes like cellulases and xylanases, and lignin by oxidative ligninolytic enzymes such as lignin peroxidase (LiP), manganese peroxidase (MnP) and laccase. The examples are Abortiporus biennis, Agaricus bisporus, Dichomitus squalens, Pleurotus eryngii, Pleurotus sajor-caju, Pleurotus ostreatus, Pleurotus flabellatus, Pleurotus floridanus, Phanerochaete chrysosporium, Ganoderma sp. rckk02, Crinipellis sp., Pycnoporous sangeus, Coriolus versicolor, Lenzites striata, Poria plascenta, etc.

\section{Soft-rot fungi}

Soft-rot fungi leaves the attacked lignocellulosic material watery-soft and breaks down cellulose and hemicelluloses (Chahal and Moo-Young, 1981). Example include Chaetomium cellulolyticum.

\section{BIOCONVERSION OF LIGNOCELLULOSIC RESIDUES AS RUMINANT FEEDS BY SOLID STATE FERMENTATION (SSF)}

Zadražil et al. (1999) defined SSF as a process, in which solid substrates are decomposed by known pure or mixed cultures of microorganisms (mainly fungi, which can grow on and through the substrate) under controlled conditions, with the aim of producing a high quality standardized products (different from composting). SSF is a polyfactorial event, in which the fungus, its enzymes, physical structure of substrate, physiological factors of fermentation and, culture and nutritional conditions play an important role in controlling lignin degradation and digestibility of fermented substrate (Zadražil, 1986). Kamra and Zadražil (1988) suggested that an improvement in lignocellulose digestibility must be the aim of the bioconversion process when the product is destined for ruminant nutrition that is proposed process of biological upgrading of lignocellulosics into animal feed should be characterized by marked lignin decomposition and liberation of nutrients from the lignocellulose-matrix with contemporary accumulation of digestible substances (Zadražil et al., 1999) along with enriching the final product with microbial protein (Villas-Bôas et al., 2002). In order to promote the delignification of a lignocellulosic substrate, it is also essential to maximize the rate as well as the specificity of lignin molecule degradation, avoiding polysaccharide consumption (Kerem and Hadar, 1995). However, the knowledge of regulating mechanisms that pro-mote selective delignification is limited (Reid and Deschamps, 1990; Kerem and Hadar, 1995; Ardon et al., 1998).

Villas-Bôas et al. (2002) stated that the bioconversion of lignocellulose into protein-rich animal feed results in a relatively lower digestibility of the fermented product than the unfermented lignocelluloses, as the basic principles of improvement in digestibility and protein enrichment are known to be antagonistic to each other. Furthermore, lignin content alone does not explain digestibility or intake sufficiently, and the degree of lignin-hemicellulose bonding might also be responsible for poor nutritive quality of biologically treated straws (Singh and Schiere, 1993). Some fungi grow on the straw but reduce the digestibility of fermented product (Ulmer et al., 1981). Zadražil (1980) also reported decreased digestibility in some cases after fungal treatment with Agrocybe aegerita which was unable to break the lignocellulose complex. Such organisms, which are generally brown rot and sweet rot fungi, utilize cellulose, hemicellulose and other soluble carbohydrate fractions for their growth leaving behind residues of low digestibility (Kundu et al., 2005). Likewise, Jalc et al. (1994) also showed that bioconversion of wheat straw with Polyporus ciliates improves the digestibility whereas with Lentinus tigrinus, the digestibility was reduced.

\section{CHEMICAL COMPOSITION AND IN VITRO DIGESTIBILITY OF FUNGAL TREATED CROP RESIDUES}

Digestibility of the straw is dependent on the deploymerisation of its structural carbohydrates. Enzymatic degradation of these macromolecules in the straw will result in degradation and increase in digestibility and availability of carbohydrates (Giovannozzi-Sermanii et al., 1989; Fazaeli et al., 2004).

Although several species of higher fungi possess ligninolytic activity, Pleurotus sp. is the most studied fungi since they improved the digestibility (Kundu et al., 2005) and nutritional quality of straws (Streeter et al., 1982; Kakkar et al., 1990). These straws contain more of free sugars, more protein with less cellulose and lignin and an increased content of ash compared to the beginning material (Rajarathnam and Bano, 1989). According to the study of Zadražil (1997), the in vitro dry matter digestibility (IVD) of spent wheat straw increased to the extent of 4.4 to $8.9 \%$ after culture and harvesting of Pleurotus ostreatus mushrooms. Calzada et al. (1987) found that for SSF of wheat straw by $P$. ostreatus for a 30 day period, the lignin content decreased significantly and IVD increased from 14.3 to $29.5 \%$. Ramirez-Bribiesca et al. (2010) reported that $P$. ostreatus treatment for 15 days on corn straw increased crude protein (39.5\%) and soluble protein (165\%), soluble carbohydrates (621\%), ash (188.32\%) and decreased neutral detergent fibre (14.5\%). Langar et al. (1980) cultivated edible mushrooms such as Agaricus bisporus (26-30 days) and Volvariella diplasia (28-30 days) on wheat straw and showed an increase (\% increase in fermented straw) in CP $(14.3,8.6)$, cellsolubles $(52.2,24.1)$ and lignin $(13.2,10.8)$ contents in the post-fungal harvested straw compared to original straw, whereas CF $(20.5,28.5)$, cellulose $(12.4,31.5)$ and hemicellulose $(0.06,16.5)$ contents decreased for $A$. bisporus and $V$. diplasia, respectively. In the case of Sporotrichum pulverulentum, Nikhat et al. (1983) observed 
an increased digestibility of wheat straw from 16 to $34 \%$ at the expense of the lignin and cellulose and Zadražil and Brunnert (1980) obtained even a higher digestibility upto 40 to $50 \%$.

Zadražil (1985) tested around 200 white rot fungal cultures on wheat straw and found an increase in IVD from 15 to $32 \%$ in most of the cases, depending upon temperature and period of fermentation. Kamra and Zadražil (1987) suggested that the IVD of lignocellulosic substrates is one of the most important criteria for the selection of fungal cultures; however, if OM loss and OM intake by animals are not taken into account, the results of IVD alone could be misleading as many edible fungi consume majority of soluble sugars and hemicelluloses which are easily digestible by ruminants (Kewalramani et al., 1988). In most of the studies, dry matter (DM) losses varied widely from 6 to $40 \%$ depending on the organism used, duration of fermentation, type of substrate and environmental conditions (Agosin and Odier, 1985). Gupta (1988) developed 'Karnal process' at National Dairy Research Institute (Karnal) which was essentially a biological treatment of lignocellulosics in a SSF using WRF Coprinus fimetarius under non-sterile conditions, consisting of two stages. The total period for fungal treatment of cereal straws through two stage Karnal process was 35 days (first stage: 30 days for urea treatment + second stage: 5 days for SSF). Although CP content increased to 13 to $14 \%$, the DM loss was more than $25 \%$ and was also found to be uneconomical (Gupta et al., 1993).

Jung et al. (1992) also noted large losses of DM (11.7 to $42.3 \%$ ) for five white-rot basidiomycetes (Phanerochaete chrysosporium, Scytinostroma galactinum, Phlebia tremellosa, Phellinus pini and Pholiota mutabilis) grown on oat straw and alfalfa stems. Further, they observed that cell wall polysaccharides were removed from both substrates by fungal activity and only $P$. chrysosporium increased IVD of oat straw (44.1\%), but all other species decreased IVD of alfalfa stems, presumably because the fungi removed the most readily fermentable polysaccharides. In spite of increased IVD and efficient lignin degradation, $P$. chrysosporium was declared unfit for practical animal feed production owing to huge OM loss (Jung et al., 1992). Zadražil and Puniya (1995) also noted a raise in in vitro OM digestibility (3 to $16 \%$ ) of bagasse by culturing with $P$. eryngii. Karunanandaa and Varga (1996a) reported that fungal (Cyathus stercoreus) treated rice straw diet (75:25 straw: concentrate) increased the digestion of cellulose (27\%) and glucose $(38 \%)$ during continuous culture but that of hemicellulose (37\%), arabinose and xyloses were decreased in addition to reduced CP availability for microbial digestion. Karunanandaa and Varga (1996b) also showed an increased IVD of rice leaf colonized by $C$. stercoreus and Pleurotus sajor-caju with an increased digestion of cellulose. Akin et al. (1996) reported that cell walls in alfalfa stems are more resistant to biological delignification than those in grasses, which can be biodegraded using $C$. stercoreus fungi.

Adamovic et al. (1998) cultivated $P$. ostreatus on wheat straw and after seeding, neutral detergent fibre (NDF) and acid detergent fibre (ADF) contents were decreased to the tune of 58 and $73.44 \%$, respectively without pronounced lignin decomposition (Table 4). Díaz-Godínez and Sánchez (2002) found that maize straw after harvesting edible mushroom ( $P$. ostreatus) on it, contained less NDF whereas ash, water soluble protein and water soluble carbohydrates increased favourably resulting in better in situ digestibility. Silva et al. (2002) reported reduced fibre and CP levels with a concomitant raise in ash content of Pleurotus pulmonaris grown substrates. Nutritional profile of fermented finger millet (Eleucine coracana) straw using brown-rot fungi Ceratocystis culmi, Tyromyces palustris and Aspergillus terries showed a favorable decrease in lignin content from the initial value of 6.68 to $3.68 \%$ after SSF (Sridhar and Senani, 2007). They concluded that $C$. culmi was the most effective with regard to lignin break down followed by $T$. palustris while $A$. terries failed to cause any significant change. In another study of SSF of finger millet straw with different strains of white-rot fungi viz. Pleurotus sajor-caju, $P$. ostreatus, Voriella volvoraceae, Phanerochaete chrysosporium and Trametes hirsuta, a linear increase in IVD was recorded with all the five fungi (Sridhar et al., 2007). Lignin degradation of mustard (Brassica compestris) straw was highest with Phanerochaete chrysosporium treated straw than Ganoderma applanatum while, IVD and CP enrichment was more with Coriolus versicolor cultured straw (Tripathi et al., 2008). A synergistic response with different fungal strains (Pycnoporus sanguineus and Oideodendron echinula) on lignin biodegradation and enrichment of wheat straw with microbial protein was achieved by Wadhwa et al. (2008).

Arora and Sharma (2009) also conducted the SSF of wheat straw obtained from different regions of India with four different WRF viz. Phlebia brevispora, $P$. fascicularia, $P$. floridensis and $P$. radiata, and observed that $P$. brevispora was found to be the best organism which degraded more than $30 \%$ lignin in all the straw samples irrespective of the region, along with good laccase production, which might be a reason for its better ligninolytic ability. As a result of higher ligninolysis, the organism was also able to enhance the digestibility (from 17.2 to $28.7 \%$ ) upto a significant level and a strong positive correlation between the two were observed. In other experiment, $50 \%$ increase in IVD was observed with P. floridensis (Sharma and Arora, 2010). Increased in vitro digestibility of Madake bamboo (Phyllostachys bambusoides) by SSF with white rot Ceriporiopsis subvermispora for 10 weeks was observed by Okano et al. (2009). Vadiveloo et al. (2009) reported that SSF of rice husk for 25 days with Pleurotus sajor-caju increased IVD and CP content without any organic matter loss.

Akinfemi (2010) reported that CP content of peanut husk improved with $P$. ostreatus (9.29\%) and with P. pulmonaris 
Table 4. Changes in the composition of wheat straw incubated with Pleurotus ostreatus mycelium ( $\left.\mathrm{g} \mathrm{kg}^{-1} \mathrm{DM}\right)$.

\begin{tabular}{cccccccccc}
\hline Day of incubation & DM & CP & EE & Ash & NDF & ADF & Hemicellulose & Cellulose & Lignin \\
\hline 0 & 195 & 38 & 19 & 63 & 824 & 561 & 263 & 453 & 109 \\
15 & 183 & 40 & 15 & 63 & 770 & 560 & 210 & 472 \\
30 & 193 & 43 & 16 & 64 & 714 & 523 & 192 & 436 \\
45 & 215 & 44 & 16 & 70 & 689 & 513 & 176 & 433 \\
60 & 223 & 46 & 17 & 74 & 657 & 473 & 184 & 398 \\
90 & 245 & 45 & 15 & 84 & 561 & 421 & 141 & 76 & 346 \\
120 & 250 & 41 & 12 & 98 & 485 & 412 & 74 & 341 \\
\hline
\end{tabular}

Adapted from Adamovic et al. (1998).

(16.11\%) compared to untreated husk $(7.39 \%)$ when fermented for 21 days and depleted CF levels. Increased $\mathrm{CP}$ content of fermented substrates was associated with increased fungal biomass (Chen et al., 1995). Similar higher nutritive values were obtained for fungal treated maize cobs (Akinfemi et al., 2009a) and maize straw (Akinfemi et al., 2009b). Cyathus stercoreus was observed as the best among four WRF tested (others being Phonerochaete chrysosporium, Auricularia polytricha and Sporotrichum pulverulentum) with respect to maximum ligninolytic and minimum cellulolytic and hemicellulolytic activity leading to minimum nutrient losses (Bakshi et al., 2011). Shrivastava et al. (2011) also reported significant decrease in cell wall constituents like ADF, NDF, hemicelluloses, lignin and cellulose to the extent of 35.00 . $38.88,45.00,37.48$ and $37.86 \%$, respectively in $P$. ostreatus fermented straw, while 30.04, 33.85, 39.90, 31.29 and $34 \%$, respectively in $T$. versicolor fermented straw. However, maximum efficiency of fermentation in terms of low carbohydrate consumption per unit of lignin degradation was observed for $P$. ostreatus on the $10^{\text {th }}$ day $(17.12 \%)$ as compared to $T$. versicolor on the 30th day $(16.91 \%)$. The myco-straw thus produced was found to contain high crude protein (CP; $4.77 \%$ T. versicolor, $5.08 \% P$. ostreatus) as compared to untreated straw (3.37\%). Shrivastava et al. (2012) reported an improved organic matter digestibility (OMD) of wheat straw $(32.22 \%)$ with Ganoderma sp. rckk02 and as a result of fungal growth, a significant decrease in ADF (24.77\%), NDF (31.03\%), hemicelllose $(42.51 \%)$, lignin $(34.95 \%)$ and cellulose $(34.33 \%)$ contents were observed on $15^{\text {th }}$ day. These recent studies clearly indicate the nutritional improvement of poor quality straws by fungal fermentation under SSF. Recently, Hassim et al. (2012) observed an increase in in vitro apparently degradable carbohydrates of oil palm fronds inoculated with WRF Ceriporiopsis subvermispora (3 weeks) and Lentinula edodes (9 weeks) up to 13 and $10 \%$, respectively.

\section{FUNGAL TREATED STRAW IN THE RATION OF RUMINANTS}

\section{Effect on nutrient utilization and growth performance}

Majority of the animal trials on utilization of fungal treated crop residues reported a positive response in terms of nutrient utilization, nitrogen $(\mathrm{N})$ balance as well as gain in body weight (Walli et al., 1988; Fazaeli et al., 2002; Kabirifard et al., 2007; Mahesh 2012; Omer et al., 2012; Shrivastava et al., 2012) although it is not consistent with all types of WRF. Spent straw remaining after edible mushroom harvesting (called spent mushroom substrate), generally contains an increased $\mathrm{CP}$, cell-wall solubles (Langar et al., 1980), total and acid insoluble ash and reduced cell wall components which might be more useful than the original straw for feeding ruminants. Meanwhile, inclusion (up to $25 \%$ ) of spent wheat straw obtained from cultivation of Agaricus bisporus mushroom in the diet of buffaloes resulted in a similar nutrient digestibility but a lower DM intake (Langar et al., 1982). Ward and Perry (1982) found an improved digestibility of DM and NFE of corn cobs treated with Trichoderma viride in lambs. Bakshi et al. (1985) also reported that the spent straw had lower digestibility of nutrients and was thus, of poor quality due to high losses of nutrients during Pleurotus growth and much increase in the ash content.

Walli et al. (1988) observed that the $\mathrm{N}$ intake, its digestion and retention in cross-bred calves fed fungal treated wheat straw supplemented with groundnut cake was higher than urea treated straw fed group. Kakkar et al. (1990) investigated the effect of replacement of wheat straw with Pleurotus treated straw in the diets of buffaloes where the animals received larger quantities of treated straw upto 2 to $4 \mathrm{~kg}$ per day and their daily gain was lower between which indicated that spent straw was as good as untreated straw for feeding buffaloes. Bakshi and Langar (1991) showed that Agaricus bisporus spent wheat straw (SWS) mixed with untreated wheat straw and $200 \mathrm{~g}$ cereal can meet the daily digestible crude protein (DCP) and total digestible nutrients (TDN) requirements of an adult ruminant as SWS contained $5.56 \%$ DCP and $29.3 \%$ TDN. Mushroom ( $P$. ostreatus) harvested spent compost in the diet of Simmenthal heifers significantly reduced weight gain at more than $17 \%$ inclusion level in the total mixed ration (Adamovic et al., 1998). In contrast, increased voluntary daily intake as well as gain in body weight of Pelibuey sheep fed with spent maize straw of $P$. ostreatus was observed by DíazGodínez and Sánchez (2002). Intake and digestibility of DM and OM was increased by more than $10 \%$ in cattle 
consuming fungal treated wheat straw diet (Fazaeli et al., 2002) and palm leaves treated with Pleurotus florida for sheep (Kabirifard et al., 2007). Fazaeli and Shafeyi (2003) suggested that Agaricus bisporus harvested spent wheat straw could be included up to $15 \%$ of the diet for finishing lambs beyond which intake as well as nutrient balance would be reduced due to high mineral content. Fermentation of wheat straw by Coprinus fimetarius is effective in improving $\mathrm{N}$ status of the straw but it was found to be unfit for feeding goats as the fermented material was less palatable and reduced the intake and also adversely affected the growth rate (Dahiya et al., 2004).

While assessing the effect of incorporation of wheat straw-rice straw (WS-RS in 50:50 ratio) or Pleurotus florida harvested spent WS-spent RS (50:50) in kids, Kaur et al. (2010) observed a higher DM intake (0.80 vs. $0.65 \mathrm{~kg} \mathrm{~d}^{-1}$ ), digestibility of majority of nutrients (except cellulose which was depressed), N-retention (5.36 vs. $4.87 \mathrm{~g})$, apparent biological value (63.08 vs. $53.43 \%)$ and daily live weight gain were comparable in both the groups. Ramirez-Bribiesca et al. (2010) evaluated the influence of $P$. ostreatus spent corn straw on the performance of feedlot Pelibuey lambs and found that average daily gain (ADG) increased to $17.5 \%$ in treatment group which received $9 \%$ of pro-farming straw from $P$. ostreatus. A significantly increased DM intake and growth rates were noted by Akinfemi and Ladipo (2011) in West African dwarf lambs fed with biologically treated maize cobs replacing wheat offal in guinea grass (Panicum maximum) based diets. Abdel-Azim et al. (2011) treated rice straw and corn stalks with Trichoderma viride, which improved their feeding value resulting in higher intake, $\mathrm{N}$ balance and growth rate in cross-bred lambs. Kim et al. (2011) fermented the oyster mushroom ( $P$. ostreatus) spent substrate with selective lactic acid producing bacteria and supplemented at $10 \%$ level in calf starter diet which improved average daily gain and feed efficiency of post weaning calves. Recently, Shrivastava et al. (2012) reported that feeding wheat straw fermented with WRF Ganoderma sp. rckk02 improved DM intake, $\mathrm{DCP}, \mathrm{TDN}$ and $\mathrm{N}$ retention in goats suggesting that the fungi holds potential in improving the nutritive value of straw. Omer et al. (2012) had shown that biologically treated corn stalks (using Trichoderma ressi) can completely replace clover hay in the ration of growing sheep which was evident by a favourable increase in DM intake, and an improvement in the digestibility of all nutrients with higher ADG. These reports clearly indicate that majority of the fungal treated spent substrates are less palatable, which can easily be improved by either ensiling or mixing with more palatable feeds (Kamra and Zadražil, 1988).

\section{Effect of fungal treated wheat straw based diets on lactation performances in cows}

Adequate levels of high quality forage NDF in the lactating cow diets are necessary to maintain optimum rumen functions and to maximize milk yield (Robinson and McQueen, 1992). In this regard, Fazaeli et al. (2002) studied the effect of fungal (Pleurotus ostreatus coded P41) treated wheat straw in the diet of lactating Holstein cows at $0,10,20$ and $30 \%$ levels. The daily intake of DM, $\mathrm{OM}, \mathrm{CP}$ and TDN was not affected by substitution of alfalfa hay with fungal treated wheat straw. Inclusion of treated straw at these levels did not affect the digestibility of nutrients, except for the ADF that was significantly reduced $(35.4 \%$ vs. 38.7$)$ at $30 \%$ level of inclusion. Body weight gain was more at $20 \%$ inclusion level, but the daily milk yield and its composition were not affected by treated straw. Further, Fazaeli et al. (2004) reported that inclusion of fungal treated straw upto $30 \%$ of the total mixed ration in late lactating Holstein cows improved the nutrients digestibility and also noted an increase in fat corrected milk yield by $13 \%$ and daily average body weight gain by 2.7 times.

\section{In vitro gas production profiles and associated parameters of fungal treated substrates}

Gases produced during rumen fermentation are waste products and of no nutritive value to the ruminants, but gas production tests are routinely used in feed research as gas volumes are related to both the extent and rate of substrate degradation (Blümmel et al., 1997). Thus in vitro gas production (IVGP) technique (Menke and Steingass, 1988) is used widely in animal nutrition for feed evaluation and to study the kinetics of microbial fermentation processes in the digestive tract. Krishnamoorthy et al. (1995) also suggested that IVGP technique should be considered for estimating metabolizable energy (ME) in tropical feedstuffs, as other methods are time consuming and costly. Gas production and associated in vitro parameters are presented in Table 5.

Gupta et al. (1992) described that the gas produced in the straw comprises of two phases; one being the soluble phase (rapid gas production) contributed by soluble portion of the straw and the other contributed by the insoluble fibrous portion of cell-wall. Further, Cone et al. (1997) described third phase of gas production, which is contributed by microbial turnover. As cell wall components (NDF and ADF) are known to have a negative correlation with gas production (Sallam et al., 2007), and thus readily available soluble carbohydrate fractions found in fungal treated substrates are expected to produce more gas (Chumpawadee et al., 2007) and short chain fatty acids (SCFA), with an increased ME contents (Akinfemi, 2010; Shrivastava et al., 2011, 2012; Mahesh, 2012). Accordingly, Okano et al. (2005) reported a higher gas production in wheat straw treated with Pleurotus sp. Higher cumulative gas production was also observed by Suzuki et al. (1995), Valizadeh et al. (2008) and Akinfemi (2010) for white rotted (shiitake and nameko mushrooms) woody 
Table 5. In vitro evaluation of fungal treated substrates using gas production test.

\begin{tabular}{|c|c|c|c|c|c|}
\hline Reference & Substrate(s) & Organism(s) & $\mathrm{GV}-24 \mathrm{~h}^{\#}\left(\mathrm{ml} \mathrm{g}{ }^{-1} \mathrm{DM}\right)$ & OMD (\%) & ME $\left(\mathrm{MJ} \mathrm{kg}^{-1}\right)$ \\
\hline Okano et al. (2005) & Wheat straw & Pleurotus sp. & $135-140$ & - & - \\
\hline Okano et al. (2009) & Madake bamboo & Ceriporiopsis subvermispora & $151^{*}$ & $65.90^{* *}$ & - \\
\hline \multirow{2}{*}{ Akinfemi et al. (2009a) } & \multirow{2}{*}{ Maize cobs } & P. pulmonaris & 116.65 & 42.09 & 6.04 \\
\hline & & P. sajor-caju & 113.35 & 41.57 & 5.94 \\
\hline \multirow{2}{*}{ Akinfemi et al. (2009b) } & \multirow{2}{*}{ Maize straw } & P. pulmonaris & 131.5 & 49.11 & 6.41 \\
\hline & & P. sajor-caju & 138.5 & 51.12 & 6.75 \\
\hline \multirow{2}{*}{ Akinfemi (2010) } & \multirow{2}{*}{ Pea nut husk } & P. ostreatus & 206.50 & 60.90 & 8.40 \\
\hline & & P. pulmonaris & 200 & 63.20 & 8.61 \\
\hline Kaur et al. (2010) & $\begin{array}{l}\text { Wheat straw: } \\
\text { Rice straw }(1: 1)\end{array}$ & P. florida & 74.82 & 44.54 & - \\
\hline \multirow{2}{*}{ Shrivastava et al. (2011) } & \multirow{2}{*}{ Wheat straw } & P. ostreatus & 91.25 & 33.39 & 4.92 \\
\hline & & Trametes versicolor & 81.25 & 31.74 & 4.66 \\
\hline Shrivastava et al. (2012) & Wheat straw & Ganoderma sp. rckk02 & 88.75 & 33.40 & 4.87 \\
\hline \multirow{2}{*}{ Mahesh (2012) } & \multirow{2}{*}{ Wheat straw } & Crinipellis sp. & 155 & 40.58 & 5.45 \\
\hline & & RCK-3 isolate & 160 & 44.63 & 5.67 \\
\hline
\end{tabular}

\#Net in vitro gas volume produced by the feed substrate after $24 \mathrm{~h}$ of incubation; *expressed as GV-48 $\mathrm{h}\left(\mathrm{ml} \mathrm{g}{ }^{-1} \mathrm{OM}\right)$; **after $48 \mathrm{~h}$ of incubation.

Table 6. Rumen fermentation parameters $\left(\mathrm{pH}, \mathrm{TVFA}, \mathrm{NH}_{3}-\mathrm{N}\right)$ as affected by fungal treated substrates.

\begin{tabular}{|c|c|c|c|c|c|c|}
\hline \multicolumn{2}{|l|}{ Reference } & \multirow{2}{*}{$\begin{array}{l}\text { Substrate(s) } \\
\text { Rice straw }\end{array}$} & \multirow{2}{*}{$\begin{array}{l}\text { Organism(s) } \\
\text { Cyathus stercoreus }\end{array}$} & \multirow{2}{*}{$\frac{\mathrm{pH}}{6.0^{*}}$} & \multirow{2}{*}{$\frac{\text { TVFA }\left(\mathrm{mmol}^{\left.100 \mathrm{ml}^{-1}\right)}\right.}{14.18}$} & \multirow{2}{*}{$\frac{\mathrm{NH}_{3}-\mathrm{N}\left(\mathrm{mg} \mathrm{dl}^{-1}\right)}{0.77^{\star}}$} \\
\hline $\begin{array}{l}\text { Karunanandaa and } \\
\text { (1996a) }\end{array}$ & Varga & & & & & \\
\hline \multirow{6}{*}{$\begin{array}{l}\text { Karunanandaa } \\
\text { (1996b) }\end{array}$} & \multirow{6}{*}{ Varga } & Rice leaf & Cyuthus stercoreus & - & 30.3 & 18.1 \\
\hline & & Rice stem & Cyuthus stercoreus & - & $6.7^{*}$ & 15.3 \\
\hline & & Rice leaf & $\begin{array}{l}\text { Phanerochaete } \\
\text { chrysosporium }\end{array}$ & - & $7.8^{\star}$ & 16.8 \\
\hline & & Rice stem & $\begin{array}{l}\text { Phanerochaete } \\
\text { chrysosporium }\end{array}$ & - & $4.4^{*}$ & 16.4 \\
\hline & & Rice leaf & Pleurotus sajorcaju & - & 27.1 & 16.1 \\
\hline & & Rice stem & Pleurotus sajorcaju & - & 29.5 & 13.3 \\
\hline \multirow{2}{*}{\multicolumn{2}{|c|}{$\begin{array}{l}\text { Omer et al. (2012) } \\
\text { Tripathi et al. (2008) }\end{array}$}} & Corn stalks & Trichoderma ressi & 6.98 & 13.46 & 18.81 \\
\hline & & Mustard straw & Coriolus versicolor & 7.19 & 7.98 & 20.34 \\
\hline \multicolumn{2}{|l|}{ Salman et al. (2008) } & $\begin{array}{l}\text { Sugar beet } \\
\text { pulp }\end{array}$ & Trichoderma viride & 6.47 & 12.81 & 23.57 \\
\hline \multirow{3}{*}{\multicolumn{2}{|c|}{$\begin{array}{l}\text { Akinfemi and Ladipo (2011) } \\
\text { Mahesh (2012) }\end{array}$}} & Maize cob & Pleurotus tuber-reguim & 9.08 & 12.84 & 26.40 \\
\hline & & Wheat straw & Crinipellis sp. & - & 2.25 & 7.52 \\
\hline & & Wheat straw & RCK-SC isolate & - & 2.33 & 6.65 \\
\hline
\end{tabular}

*Values decreased significantly $(P<0.05)$ as compared to the control.

materials, Pleurotus ostreatus treated wheat straw and peanut husk fermented with Pleurotus ostreatus and $P$. pulmonaris, respectively. Okano et al. (2009) also correlated a decrease in $\mathrm{OM}$, cell wall components and lignin with an increase in in vitro digestibility of OM, NDF and IVGP after 10 weeks of SSF of Madake bamboo. However, Kaur et al. (2010) found lower net gas production in spent wheat straw and rice straw (Pleurotus florida) at $1: 1$ ratio with a higher partitioning factor, a measure of efficiency of microbial protein synthesis (Blümmel et al., 1997).

\section{Effect on rumen fermentation parameters}

Fermentationpatternobservedwithfungaltreatedsubstrates upon microbial digestion favourably altered ruminal parameters because of bio-delignification by WRF which enables faster accessibility by rumen microbes. Conse- 
quently, higher levels of total volatile fatty acids (TVFA), acetate to propionate ratio $(A: P)$ and variable ammonia nitrogen $\left(\mathrm{NH}_{3}-\mathrm{N}\right)$ are produced (Table 6). Karunanandaa and Varga (1996a) found that fungal (Cyathus stercoreus) treated rice straw diet produced an increased TVFA with an increased molar proportion of propionate and butyrate. But $\mathrm{pH}$ and $\mathrm{NH}_{3}-\mathrm{N}$ production was reduced. Higher TVFA concentration was also observed by Suzuki et al. (1995) with fungal (Shiitake and nameko mushrooms) rotted woody materials. In another study, Karunanandaa and Varga (1996b) compared rumen fermentation pattern of different morphological fractions of rice straw colonized by different WRF (for 30 days) and found that TVFA production increased by $75 \%$ and $25 \%$ for leaf and stems colonized by Cyathus stercoreus (Cs) and Pleurotus sajor-caju (Ps), respectively compared to Phanerochaete chrysosporium. Further, A:P ratio and $\mathrm{NH}_{3}-\mathrm{N}$ were higher in both fractions colonized by $\mathrm{Cs}$ and Ps. Abo-Donia et al. (2005) and Omer et al. (2012) reported that ruminal $\mathrm{pH}$ and the $\mathrm{NH}_{3}-\mathrm{N}$ concentration in the rumen liquor increased significantly in biologically treated peanut hulls and sugarcane bagasse, and Trichoderma ressi treated corn stalks, respectively besides a higher TVFA concentration (Omer et al., 2012). Higher $\mathrm{NH}_{3}-\mathrm{N}$ levels were also recorded by Salman et al. (2008), Akinfemi and Ladipo (2011) and Mahesh (2012) with fungal treated sugar beet pulp, maize cobs and wheat straw, respectively. Tripathi et al. (2008) found that bio-processed mustard straw with $C$. versicolor (21 days) increased rumen $\mathrm{pH}$ and TVFA after $6 \mathrm{~h}$ of feeding in sheep. Further, cultured straw increased small holotricks but reduced large holotricks population in rumen liquor, while no effect on ruminal microbial enzyme activities was observed. These studies imply that most of the microbially converted feeds are safer and the potential biohazards associated with them are very low (VillasBôas et al., 2002) for ruminants.

\section{Methane production from fungal treated substrates}

Enteric methane $\left(\mathrm{CH}_{4}\right)$ production arises principally from microbial fermentation of hydrolyzed dietary carbohydrates such as cellulose, hemicellulose, pectin and starch. The amount of $\mathrm{CH}_{4}$ produced during ruminal fermentation is dependent upon the nature of the substrate being fermented. Diet composition alters the digestion efficiency of animals thereby $\mathrm{CH}_{4}$ production. In general, methanogenic potential of ruminal microflora is greatest for the fermentation of structural carbohydrates compared to that of non structural carbohydrates (Torrent et al., 1994; Johnson and Johnson, 1995; Boadi et al., 2004). This is the reason why ruminants emit more $\mathrm{CH}_{4}$ on fibrous (straw and stover) diets. Jalc et al. (1994) reported a reduction in in vitro total and individual gas (methane and $\mathrm{CO}_{2}$ ) production from wheat straw treated with Polyporus ciliates for four weeks. Akinfemi (2010) reported that $\mathrm{CH}_{4}$ $\left(\mathrm{ml} 200 \mathrm{mg}^{-1}\right)$ production in vitro from peanut husk fermen- ted for 21 days with WRF Pleurotus ostreatus (7) and $P$. pulmonaris (5) was significantly lower compared to untreated husk (8). Mahesh (2012) observed a linear reduction in $\mathrm{CH}_{4}(\%)$ from fungal treated wheat straws which contained lesser fibre fractions (NDF and ADF) than untreated straw. This could probably due to indirect effect via fibre digestion leading to lesser residency of feed particles in the rumen (Moss et al., 1994; Sallam et al., 2007). The role of quality forages in reducing enteric $\mathrm{CH}_{4}$ production in ruminants has been evident from several studies (Varga et al., 1985; Das and Singh, 1999; Singh and Mohini, 1999a, 1999b, Benchaar et al., 2001; Mohini et al., 2007). It can be concluded that enteric $\mathrm{CH}_{4}$ emissions are highest when the animal is presented with poor quality forages. Thus, by fungal treatment (via SSF), an improvement in the forage quality with respect to cell wall digestion and overall enhancement in carbohydrates digestibility as well as increased DM intake will be expected to reduce the $\mathrm{CH}_{4}$ emissions relative to nutrients digestibility, in ruminants (Mahesh, 2012).

\section{CONCLUSION AND POSSIBLE FUTURE AREAS OF THE TECHNOLOGY}

Biological treatments can be employed for improving the feeding value of low quality fibrous crop residues. The inevitable organic matter losses during biological treatments imply that an increased OM digestibility is needed to compensate for the losses. Hence, SSF for a period of 6-8 days has been recommended as the maximum time of fermentation in order to reduce DM loss (Owen et al., 2012). Although improvement in the nutritional worth of biologically treated crop residues is achieved, many are not economical and the process has not yet optimized under field conditions. Hence, the possible future of the technology should focus on the following areas.

Isolation and identification of selective and highly ligninlytic fungus in the nature and cultivating it for the commercial production of ligninase enzyme (FAO, 2011). Further, biotechnological means of genetic manipulation of ligninlytic fungus such that only lignin is degraded without any greater change in cell wall carbohydrates needs to be developed. Once the proven fungus is identified, its potential to upgrade (enhancing digestibility) various agro by-products (husks, straw, stovers, bagasse and other fibrous lignocellulosics) that are traditionally used as livestock feeds should be considered. In addition, focus should be given to develop a simple and economic technology for effective implementation especially at small and mixed farming systems in developing countries which may partially solve the ever increasing problems of feed crisis to livestock.

\section{REFERENCES}

Abdel-Azim SN, Ahmed MA, Abo-Donia F, Soliman H (2011). Evaluation of fungal treatment of some agricultural residues. Egypt. J. Sheep Goat Sci. 6:1-13. 
Abo-Donia FM, Sobhy H, El-Gamal KM, Mikhail WZA (2005). Evaluation of applying the solid state fermentation technique to upgrade chemical composition and nutritive value of peanut hulls and sugarcane bagasse. Egypt. J. Nutr. Feeds 8:603-617.

Adamovic M, Grubic G, Milenkovic I, Jovanovic R, Protic R, Sretenovic $L$, Stoicevic L (1998). The biodegradation of wheat straw by Pleurotus ostreatus mushrooms and its use in cattle feeding. Anim. Feed Sci. Technol. 71:357-362.

Agosin F, Odier E (1985). Solid state fermentation, lignin degradation and resulting digestibility of wheat straw fermented by selected whiterot fungi. Appl. Microbiol. Biotechnol. 21:397-403.

Akhtar M, Blanchette RA, Kirk TK (1997). Fungal delignification and biomechanical pulping of wood. Adv. Biochem. Eng. Biotechnol. 57:159-195.

Akin DE, Morrison III WH, Rigsby LL, Gamble GR, Sethuraman A, Eriksson KEL (1996). Biological delignification of plant components by the white rot fungi Ceriporiopsis subvermispora and Cyathus stercoreus. Anim. Feed Sci. Technol. 63:305-321.

Akin, DE, Sethuraman A, Morrison III WH, Martin SA, Erickson K (1993). Microbial delignification with white-rot fungi improves forage digestibility. Appl. Environ. Microbiol. 59:4274-4282.

Akinfemi A (2010). Bioconversion of peanut husk with white rot fungi: Pleurotus ostreatus and Pleurotus pulmonarius. Livest. Res. Rural Develop. 22:3.

Akinfemi A, Adu OA, Adebiyi OA (2009b). Use of white rot-fungi in upgrading maize straw and, the resulting impact on chemical composition and in vitro digestibility. Livest. Res. Rural Develop. 21:10.

Akinfemi A, Adu OA, Doherty F (2009a). Assessment of the nutritive value of fungi treated maize cob using in vitro gas production technique. Livest. Res. Rural Develop. 21:11.

Akinfemi A, Ladipo MK (2011). Effect of fungal treated maize cob on the performance of west african dwarf rams. Conference on International Research on Food Security, Natural Resource Management and Rural Development. University of Bonn (October 5-7).

Ardon O, Kerem Z, Hadar Y (1998). Enhancement of lignin degradation and laccase activity in Pleurotus ostreatus by cotton stalk extract. Can. J. Microbiol. 44:676-680.

Arora DS, Sharma RK (2009). Comparative ligninolytic potential of Phlebia species and their role in improvement of in vitro digestibility of wheat straw. J. Anim. Feed Sci. 18: 151-161.

Bakshi MPS, Langar PN (1991). Agaricus bisporus-harvested spent wheat straw as livestock feed. Indian J. Anim. Sci. 61:653-654.

Bakshi MPS, Wadhwa M, Gangwar M, Lamba JS (2011). Biodegradation of wheat straw by lignolytic fungi. Indian J. Anim. Nutr. 28:371-376.

Bakshi, MPS, Gupta VK, Langar PN (1985). Acceptability and nutritive evaluation of Pleurotus harvested spent wheat straw in buffaloes. Agric. Wastes 13:51.

Basu S, Gaur R, Gomes J, Sreekrishnan TR, Bisaria VS (2002). Effect of seed culture on solid state bioconversion of wheat straw by Phanerochaete chrysosporium for animal feed production. J. Biosci. Bioeng. 1:25-30.

Benchaar C, Pomar C, Chiquette J (2001). Evaluation of dietary strategies to reduce methane production in ruminants: A modeling approach. Can. J. Anim. Sci. 81:5632-574.

Blümmel M, Makkar HPS, Becker K (1997). In vitro gas production: a technique revisited. J. Anim. Physiol. Anim. Nutr. 77:24-34.

Boadi D, Benchaar C, Chiquette J, Masse D (2004). Mitigation strategies to reduce enteric methane emissions from dairy cows: Updated review. Can. J. Anim. Sci. 84:319-335.

Calzada JF, Franco LF, De Arriola MC (1987). Acceptability, body weight changes and digestibility of spent wheat straw after harvesting of Pleurotus sajor-caju. Biol. Wastes. 22:303-309.

Chahal DS, Moo-Young M (1981). Bioconversion of lignocellulosics in animal feed with Cheatomium cellulolyticum. Dev. Ind. Microbiol. 23:143-159.

Chen J, Fales SL, Varga GA, Royse DJ (1995). Biodegradation of cell wall component of maize stover colonized by white-rot fungi and resulting impact on in vitro digestibility. J. Sci. Food Agric. 68:91-98.

Chumpawadee S, Chantiratikul A, Chantiratikul P (2007). Chemical composition and nutritional evaluation of energy feeds for ruminant using in vitro gas production technique. Pak. J. Nutr. 6:607-612.

Cone JW, van Gelder AH, Driehuis, F (1997). Description of gas production profiles with a three-phasic model. Anim. Feed Sci. Technol. 66:31-45.

Dahiya DS, Khatta VK, Kumar N, Mann NS (2004). Fungal treatment of crop residues by Coprinus fimetarius and its utilization by goats. Ind. J. Dairy Sci. 57:122-126.

Das A, Singh GP (1999). Effect of different proportions of berseem and wheat straw on in vitro dry matter digestibility and total gas production. Indian J. Anim. Nutr. 16:60-64.

Díaz-Godínez G, Sánchez C (2002). In situ digestibility and nutritive value of maize straw generated after Pleurotus ostreatus cultivation. Can. J. Anim. Sci. 82:617-619.

Fan LT, Lee YH, Beardmore DR (1981). Mechanism of enzymatic hydrolysis cellulose: Effect of major structural features of cellulose on enzymatic hydrolysis. Biotechnol. Bioeng. 23:419.

FAO (2011). Successes and failures with animal nutrition practices and technologies in developing countries. Proceedings of the FAO Electronic Conference, 1-30 September 2010, Rome, Italy. Edited by Harinder PS Makkar. FAO Animal Production and Health Proceedings. No. 11. Rome, Italy.

Fazaeli $\mathrm{H}$, Jelan ZA, Azizi A (2002). Effects of fungal treatment on nutritive value of wheat straw. Malaysian J. Anim. Sci. 7:61-71.

Fazaeli H, Mahmodzadeh H, Jelan ZA, Rouzbenhan Y, Liang JB, Azizi A (2004). Utilization of fungal treated wheat straw in the diet of late lactating cow. Asian-Aust. J. Anim. Sci. 2004. 17:467-472.

Fazaeli H, Shafeyi A (2003). Use of mushroom spent wheat straw compost as animal feed. Proceedings of fifth international conference on mushroom biology and mushroom products. Vol.12, Supplement.

Giovannozzi-Sermanii G, Bertoni G, Porri A (1989). Biotransformation of straw to commodity chemicals and animal feeds. In: Enzyme Systems for Lignocellulose Degradation (Eds.) W Coughlan. Amsterdam: Elsevier Sciences. pp. 371-382.

Gupta BN (1988). Development and concept of Karnal process for fungal treatment of cereal straws, Proc. of intern. Workshop in Fibrous Crop Residues as Animal Feeds. 27-28 October, NDRI (SRS), Bangalore, India. pp. 46.

Gupta BN, Singh GP, Singh K (1992). Effect of Coprinus fimetarius inoculated rice straw through Karnal process on gas production and in vitro rumen degradability. Indian J. Dairy Sci. 45: 53-58.

Gupta BN, Singh GP, Singh K (1993). Biological treatment of lingocellulosics as feed for animals-an overview. In: Kiran Singh and JB Schiere. (Eds) Feeding of ruminants on fibrous crop residues. Indian Council of Agricultural Research, Krishi Bhavan, New Delhi. pp. 209221.

Han YW (1975). Microbial fermentation of rice straw: Nutritive composition and in vitro digestibility of the fermentation products. Appl. Microbiol. 29:510-514.

Hassim HA, Lourenc M, Goh YM, Baars JJP, Fievez V (2012). Rumen degradation of oil palm fronds is improved through pre digestion with white rot fungi but not through supplementation with yeast or enzymes. Can. J. Anim. Sci. 92:79-87.

Jackson MG (1977). The alkali treatment of straws: A review. Anim. Feed Sci. Technol. 2:105-130.

Jalc D, Zitnan R, Nerud F (1994). Effect of fungus treated straw on ruminal fermentation in vitro. Anim. Feed Sci. Technol. 46:131-141.

Johnson KA, Johnson DE (1995). Methane emissions from cattle. J. Anim. Sci. 73:2483-2492.

Jung $H G$ (1989). Forage lignins and their effects on fibre digestibility. Agron. J. 81:33.

Jung HG, Valdez FR, Abad AR, Blanchette RA, Hatfield RD (1992). Effect of white-rot basidiomycetes on chemical composition and in vitro digestibility of oat straw and alfalfa stems. J. Anim. Sci. 70:19281935.

Kabirifard A, Kafilzadeh F, Fazaeli H (2007). Effect of Pleurotus florida on nutritive value of wheat stubble and date leaf. In: International tropical animal nutrition conference (volume II), held at National Dairy Research Institute, Karnal. pp: 105. (Abstract)

Kakkar VK, Garcha HS, Dhanda S, Makkar GS (1990). Mushroom harvested spent straw as feed for buffaloes. Indian J. Anim. Nutr. 7:267-70.

Kamra DN, Zadražil F (1987). Factors affecting micro-biological 
improvement of lignocellulosics for animal feeding. In: Kiran Singh, TW Flegel, JB Schiere (Eds), Biological, chemical and physical treatment of fibrous crop residues for use as animal feed. Proceedings of International Workshop, 20-21 January 1987, New Delhi, India.

Kamra DN, Zadražil F (1988). Microbiological improvement of lignocellulosics in animal feed production: a review. In: F Zadražil, $\mathrm{P}$ Reiniger (Eds.), Treatment of Lignocellulosics with White-Rot Fungi. Elsevier, Essex, UK, pp. 56-63.

Karunanandaa K, Vargaa GA (1996a). Colonization of rice straw by white-rot fungi (Cyathus stercoreus): Effect on ruminal fermentation pattern, nitrogen metabolism, and fibre utilization during continuous culture. Anim. Feed Sci. Technol. 61:1-16.

Karunanandaa K, Vargaa GA (1996b). Colonization of crop residues by white-rot fungi: cell wall monosaccharides, phenolic acids, ruminal fermentation characteristics and digestibility of cell wall fibre components in vitro. Anim. Feed Sci. Technol. 63:273-288.

Kaur K, Wadhwa M, Bakshi MPS (2010). Nutritional evaluation of Pleurotus florida harvested spent wheat-rice straw based diets in goats. Indian J. Anim. Sci. 80:906-909.

Keller FA, Hamillton TE, Nguyon QA (2003). Microbial pretreatment of biomass potential for reducing severity of thermo-chemical biomass pretreatment. Appl. Biochem. Biotechnol. 105:27-41.

Kerem Z, Hadar Y (1995). Effect of manganese on preferential degradation of lignin by Pleurotus ostreatus during solid-state fermentation. Appl. Environ. Microbiol. 61:3057-3062.

Kewalramani N, Kamra DN, Lall D, Pathak NN (1988). Bioconversion of sugarcane bagasse with white rot fungi. Biotechnol. Lett. 10:369372.

Khilberg R (1972). The microbes as a source of food. Ann. Rev. Microbiol. 26:427 - 436 .

Kim MK, Lee HG, Park JA, Kang SK, Choi YJ (2011). Recycling of fermented sawdust-based oyster mushroom spent substrate as a feed supplement for post-weaning calves. Asian-Aust. J. Anim. Sci. 4:493-499.

Kirk KR, Moore WE (1972). Removing lignin from wood with white-rot fungi and digestibility of resulting wood. Wood Fiber. 4:72-79.

Kolattukudy PE, Espelie KE, Soliday CL (1981). Hydrophobic layers attached to cell walls and associated waxes. Encyclopedia of Plant Physiology, New Series, 13 B: 225-254.

Krishnamoorthy U, Soller H, Steingass H, Menke KH (1995). Energy and protein evaluation of tropical feedstuffs for whole tract and ruminal digestion by chemical analysis and rumen inoculums studies in vitro. Anim. Feed Sci. Technol. 52:177-188.

Kundu SS, Mojumdar AB, Singh KK, Das MM (2005). Improvement of poor quality roughages. In: SS Kundu, SK Mahanta, S Singh, PS Pathak (Eds.) Roughage Processing Technology, Satish serial publishing house, Delhi, India. pp. 193-209.

Langar PN, Sehgal JP, Garcha HS (1980). Chemical changes in wheat and paddy straw after fungal cultivation. Indian J. Anim. Sci. 50: 942946.

Langar PN, Sehgal JP, Rana VK (1982). Utilization of Agaricus bisporus-harvested spent wheat straw in the ruminant diets. Indian J. Anim. Sci. 52: 634-637.

Mahesh MS (2012). Fungal bioremediation of wheat straw to improve the nutritive value and its effect on methane production in ruminants. MVSc thesis submitted to National Dairy Research institute (Deemed University), Karnal, Haryana, India.

McDonald P, Edwards RA, Greenhalgh JFD, Morgan CA (2009). Animal Nutrition, sixth edn, Pearson publishing. pp. 29.

Menke KH, Steingass $H$ (1988). Estimation of the energetic feed value obtained from chemical analysis and in vitro gas production using rumen fluid. Anim. Res. Dev. 28: 7-55.

Mohini M, Mani V, Singh GP (2007). Effect of different ratios of green and dry roughages on milk production and methane emission in cattle. Indian J. Anim. Sci. 77:79-82.

Moss AR, Givens DI, Garnsworthy PC (1994). The effect of alkali treatment of cereal straws on digestibility and methane production by sheep. Anim. Feed Sci. Technol. 49: 245-259.

Moyson E, Verachtert H (1991). Growth of higher fungi on wheat straw and their impact on the digestibility of the substrate. Appl. Microbiol. Biotechnol. 36:42-424.
National Research Council (NRC) (1982). United States-Canadian Tables of Feed Composition. National Academy Press, Washington, DC.

Nikhat P, Kehlon SS, Sethi RP, Chopra AK (1983). Solid substrate fermentation of wheat straw into animal feed. Indian J. Anim. Sci. 53: 1191-1194.

Okano K, Boonlue S, Suzuki Y (2005). Effect of ammonium hydroxide treatment on the in vitro dry matter digestibility and gas production of wheat straw, sugarcane bagasse medium and konara oak rotted by edible basidiomycetes. Anim. Sci. J. 76:147-152.

Okano K, Ohkoshi N, Nishiyama A, Usagawa T, Kitagawa M (2009). Improving the nutritive value of madake bamboo, Phyllostachys bambusoides, for ruminants by culturing with the white-rot fungus Ceriporiopsis subvermispora. Anim. Feed Sci. Technol. 152:278-285.

Omer HAA, Ali FAF, Gad SM (2012). Replacement of clover hay by biologically treated corn stalks in growing sheep rations. J. Agric. Sci. 4:257-268.

Owen E, Smith T, Makkar HPS (2012). Successes and failures with animal nutrition practices and technologies in developing countries: $A$ synthesis of an FAO e-conference. Anim. Feed Sci. Technol. 174: 211-226.

Prasad CS, Sampath KT, Shivaramaiah MT, Walli TK (1993). Dry matter intake, digestibility and supplementation of slender and coarse straws-A review. In: K Singh, JB Schiere (Eds.) Feeding of ruminants on fibrous crop residues. Indian Council of Agricultural Research, New Delhi. pp.188-203.

Rajarathnam S, Bano Z (1989). Pleurotus mushrooms. Biotransformations of natural lignocellulotic waste. Crit. Rev. Food Sci. Nutr. 28:31123.

Ramirez-Bribiesca JE, Soto-Sanchiez A, Hernandez-calva LM, SalinasChavira J, Galaviz-Rodriguez JR, Cruz-Monterrosa RG, VargasLopez S (2010). Influence of Pleurotus ostreatus spent corn straw on performance and carcass characteristics of feedlot Pelibuey lambs. Indian J. Anim. Sci. 80:754-757.

Reid ID, Deschamps AM (1990). Nutritional regulation of synthetic lignin (DHP) degradation by the selective white-rot fungus Phlebia (Merulius) tremellosa: effects of glucose and other co-substrates. Can. J. Bot. 69:147-155.

Robinson PH, McQueen RE (1992). Influence of rumen fermentable neutral detergent fibre levels on feed intake and milk production. J. Dairy Sci. 75: 520-532.

Sallam SMA, Nasser MEA, El-Waziry AM, Bueno ICS, Abdalla AL (2007). Use of an in vitro ruminant gas production technique to evaluate some ruminant feedstuffs. J. Appl. Sci. Res. 3:33-41.

Salman FM, El-Kadi RI, Abdel-Rahman H, Ahmed SM, Mohamed MI, Shoukry MM (2008). Biologically treated sugar beet pulp as a supplement in goat rations. Int. J. Agric. Biol. 10:412-416.

Saritha M, Arora A, Lata (2012). Biological pretreatments of lignocellulosic substrates for enhanced delignification and enzymatic digestibility. Ind. J. Microbiol. 52:122-130.

Shabtay A, Hadar Y, Eitam H, Brosh A, Orlov A, Tadmor Y, Izhaki I, Kerem Z (2009). The potential of Pleurotus treated olive mill solid waste as cattle feed. Bioresour. Technol. 100:6457-6464.

Sharma RK, Arora DS (2010). Production of lignocellulolytic enzymes and enhancement of in vitro digestibility during solid state fermentation of wheat straw by Phlebia floridensis. Bioresour. Technol.101:9248-9253.

Shrivastava B, Nandal P, Sharma A, Jain KK, Khasa YP, Das TK, Mani V, Kewalramni NJ, Kundu SS, Kuhad RC (2012). Solid state bioconversion of wheat straw into digestible and nutritive ruminant feed by Ganoderma sp. rckk02. Bioresour. Technol. 107:347-351.

Shrivastava B, Thakur S, Khasa YP, Gupte A, Puniya AK, Kuhad RC (2011). White rot fungal conversion of wheat straw to energy rich cattle feed. Biodegradation 22:823-831.

Silva SO, da Costa SMG, Clemente E (2002). Chemical composition of Pleurotus pulmonaris (Fr.) Quel., substrates and residue after cultivation. Braz. Arch. Biol. Technol. 45:531-535.

Silverstein RA, Chen Y, Sharma RR, Boyette MD, Osborne J (2007). A comparison of chemical pretreatment methods for improving saccharification of cotton stalks. Bioresour. Technol. 98:3000-3011.

Singh GP, Mohini M (1999a). Effect of different levels of berseem on in vitro digestibility and methane production in cross-bred cattle fed 
wheat straw based diets. Indian J. Dairy BioSci. 10:14-19.

Singh GP, Mohini M (1999b). Level of green maize affecting methane production on roughage based diet. Indian J. Anim. Sci. 48: 290-294.

Singh GP, Oosting SJ (1993). Nutritive value of straw. In: K Singh, JB Schiere (Eds.) Feeding of ruminants on fibrous crop residues. Indian Council of Agricultural Research, New Delhi, India. pp. 141-146.

Singh K, Schiere JB (1993). Feeding of ruminants on fibrous crop residues. Indian Council of Agricultural Research, New Delhi, India. pp.188-203.

Sridhar M, Bhatta R, Senani S (2007). Effect of solid state fermentation with different strains of white rot fungi on the in vitro digestibility of straw (Eleucine coracana). In: International tropical animal nutrition conference (volume II), held at National Dairy Research Institute, Karnal. pp.104-105. (Abstract)

Sridhar M, Senani S (2007). Nutritional profile of ragi (Eleucine coracana) straw fermented using brown rot fungi. In: International tropical animal nutrition conference (volume II), held at National Dairy Research Institute, Karnal. pp.103-104. (Abstract)

Streeter CL, Conway KE, Horn GW, Mader TL (1982). Nutritional evaluation of wheat straw incubated with the edible mushroom, Pleurotus ostreatus. J. Anim. Sci. 54: 183-188.

Suzuki Y, Okano K, Kato S (1995). Characteristics of white-rotted woody materials obtained from Shiitake mushroom (Lentinus edodes) and nameko mushroom (Pholiota nameko) cultivation with in vitro rumen fermentation. Anim. Feed Sci. Technol. 54:227-236.

Theander O, Aman P (1984). Anatomical and chemical characteristics. In: F Sundstøl, E Owen (Eds.) Straw and Other Fibrous By-products as Feed. Elsevier Science Publishers. Amsterdam, The Netherlands. Developments in Animal and Veterinary Sciences. pp. 14.

Torrent J, DE Jonhson, Roverter A (1994). Prediction of methane production in lactating cattle using rates of digestion and passage. J. Anim. Sci. 72 (suppl.) 189

Tripathi JP, Yadav JS (1992). Optimization of SSF of wheat straw into animal feed by Pleurotus ostreatus: A pilot effort. Anim. Feed. Sci. Technol. 37:59-72.

Tripathi MK, Mishra AS, Misra AK, Vaithiyanathan S, Prasad R, Jakhmola RC (2008). Selection of white-rot basidiomycetes for bioconversion of mustard (Brassica compestris) straw under solidstate fermentation into energy substrate for rumen micro-organism. Lett. Appl. Microb. 46:364-370.

Ulmer DC, Tongerdy RP, Murphy VC (1981). Solid state fermentation of steam treated feed lot waste fibre with Cheetomium cellulolyticum. Biotechnol. Bioeng. Sym. 11: 349-451.

Vadiveloo J, Nurfariza B, Fadel JG (2009). Nutritional improvement of rice husks. Anim. Feed Sci. Technol. 151:299-305.

Valizadeh R, Sobhanirad S, Mojtahedi M (2008). Chemical composition, ruminal degradability and in vitro gas production of wheat straw inoculated by Pleurotus ostreatus mushrooms. J. Anim. Vet. Adv. 7:1506-1510.

Van Soest PJ (1994). Nutritional Ecology of the Ruminant, second ed. Cornell University Press, Ithaca, NY. pp. 177.

Van Soest PJ (2006). Rice straw, the role of silica and treatments to improve quality: A review. Anim. Feed Sci. Technol.130:137-171.

Van Soest PJ, Jones LHP (1968). Effect of silica in forages upon digestibility. J. Dairy Sci. 51:1644-1648.

Varga G, Terrell HF, Waldo DR, Huntington GB, Glnn BP (1985). Effect of alfalfa or orchard grass silages on energy and nitrogen utilization for growth by Holstein steers. In: Energy Metabolism of Farm Animals. PW Mue, HF Tyrell, PJ Reynolds., (Eds,) Ronman and Littlefield, Totawa, NJ. pp. 86-89.

Villas-Bôas SG, Esposito E, Mitchell DA (2002). Microbial conversion of lignocellulosic residues for the production of animal feeds. Anim. Feed Sci. Technol. 98:1-12.

Wadhwa M, Bakshi MPS, Gangwar M, Lamba JS (2008). Impact of blend of lignolytic fungi on the biodegradation of wheat straw. Indian J. Anim. Nutr. 25: 318-323.

Walli TK, Gupta BN, Rai SN, Singh K (1988). Biological treatment of straws, N-transactions during fermentation and subsequent utilization by ruminants. In: K Singh, JB Schiere (Eds.) Fibrous Crop Residues as Animal Feed. Proceedings of International Workshop, 27-28 October 1988, ND RI (SRS), Bangalore, India. pp.75-81.
Ward JW, Perry TW (1982). Enzymatic conversion of corn cobs to glucose with Trichoderma viride fungus and the effect on nutritional value of the corn cobs. J. Anim. Sci. 54:609-617.

Yadav JS, Tripathi JP (1991). Optimization of cultivation and nutrition conditions and substrate pretreatment for solid substrate fermentation of wheat straw by Coriolus versicolor. Folia. Microbiol. 36:294-301.

Yu H, Guo G, Zhang X, Yan K, Xu C (2009). The effect of biological pretreatment with the selective white-rot fungus Echinodontium taxodii on enzymatic hydrolysis of softwoods and hardwoods. Bioresour. Technol. 100:5170-5175.

Zadražil F (1976). Ein Beitrag zur Strohzersetzung durch höhere Pilze (Basidiomyceten) und Nutzung für Ernährungs- und Düngezwecke. Sonderheft zur Z. Landwirtschaftliche Forschung XXXI, pp. 153-167.

Zadražil $F$ (1979). Umwandlung von Pflanzenabfall in Tierfutter durch höhere Pilze. Mushroom Sci. X (Part I), pp. 231-241, Bordeaux.

Zadražil $F$ (1980). Influence of ammonium nitrate and organic supplement on the yield of $P$. sajor-caju. Eur. J. Appl. Biotechnol. 2:31-35.

Zadražil $F$ (1985). Screening of fungi for lignin decomposition and conversion of straw into feed. Angew. Botanik. 59:433-452.

Zadražil F (1986). White-rot fungi and mushrooms grown on cereal straw: aim of the process, final products, scope for the future. In: JM Vandermeer, RA Rukens, MP Berranti (Eds.) Degradation of Lignocellulosics in Ruminants and in Industrial Processes. Institute for Livestock Feeding and Nutrition Research (IWO), Lelystad (Netherlands). pp. 55-62.

Zadražil F (1997). Changes in in vitro digestibility of wheat straw during fungal growth and after harvest of oyster mushrooms (Pleurotus ostreatus) on laboratory and industrial scale. J. Appl. Anim. Sci. 11:37-48.

Zadražil F, Brunnert H (1980). The influence of ammonium nitrate supplementation on degradation and in vitro digestibility of straw colonized by higher fungi. Eur. J. Appl. Microbiol. Biotechnol. 9:3744.

Zadražil F, Brunnert H (1982). Solid-state fermentation of lignocellulose containing plant residues with Sporotrichum pulverulentum Nov. and Dichomitus squalens (Karst). Reid. Eur. J. Appl. Microbiol. Biotechnol. 16:45-51.

Zadražil F, Permana IG, Wiesche C (1999). Is the conversion of lignocellulose into feed with white rot fungi realizable? Practical problems of scale up and technology transfer. Deutscher Tropentag 1999, Berlin.

Zadražil F, Puniya AK (1995). Studies on effect of particle size during solid state fermentation of sugarcane bagasse into animal feed using white-rot fungi. Bioresour. Technol. 54:85-87.

Zafar SI, Sheeraz Q, Abdullah N (1989). Degradation of the lignocellulosic component on wheat straw-Coriolus versicolor solid state fermentation under nitrogen-starved conditions. Biol. Wastes. 27:67-70.

Zhang X, Xu C, Wang H (2007). Pretreatment of bamboo residues with Coriolus versicolor for enzymatic hydrolysis. J. Biosci. Bioeng. 104:149-151. 